\title{
SELECTION OF ENDOPHYTIC FUNGI FROM COMFREY (SYMPHYTUM OFFICINALE L.) FOR IN VITRO BIOLOGICAL CONTROL OF THE PHYTOPATHOGEN SCLEROTINIA SCLEROTIORUM (LIB.)
}

\author{
Rafaeli Rocha ${ }^{\text {; }}$ Daniela Eleutério da Luz ${ }^{\text {; }}$ Cibelle Engels' ${ }^{1}$; Sônia Alvim Veiga Pileggi ${ }^{1}$; \\ David de Souza Jaccoud Filho ${ }^{2}$; Rodrigo Rodrigues Matiello²; Marcos Pileggi ${ }^{2}$ *
}

${ }^{1}$ Departamento de Biologia Estrutural, Molecular e Genética, Universidade Estadual de Ponta Grossa, Ponta Grossa, PR, Brasil; ${ }^{2}$ Departamento de Fitoterapia e Fitossanidade, Universidade Estadual de Ponta Grossa, Ponta Grossa, PR, Brasil

Submitted: June 29, 2007; Returned to authors for corrections: November 21, 2007; Approved: February 15, 2009.

\begin{abstract}
Biological control consists of using one organism to attack another that may cause economic damage to crops. Integrated Pest Management (IPM) is a very common strategy. The white mold produced by Sclerotinia sclerotiorum (Lib.) causes considerable damage to bean crops. This fungus is a soil inhabitant, the symptoms of which are characterized by water-soaked lesions covered by a white cottony fungal growth on the soil surface and/or the host plant. Possible biological control agents taken from plants are being investigated as phytopathogen inhibitors. These are endophytic microorganisms that inhabit the intercellular spaces of vegetal tissues and are often responsible for antimicrobial production. The objective of the present study was to select endophytic fungi isolated from comfrey (Symphytum officinale L.) leaves with in vitro antagonist potential against the phytopathogenic fungus $S$. sclerotiorum. Twelve isolates of endophytic fungi and a pathogenic strain of $S$. sclerotiorum were used in the challenge method. With the aid of this method, four endophytes with the best antagonistic activity against $S$. sclerotiorum were selected. Pathogen growth inhibition zones were considered indicative of antibiosis. The percentages of pathogenic mycelia growth were measured both with and without the antagonist, resulting in growth reductions of $46.7 \%$ to $50.0 \%$ for $S$. sclerotiorum. These analyses were performed by evaluating the endophytic/pathogenic mycelia growth in $\mathrm{mm}$ /day over an eight-day period of antagonistic tests.
\end{abstract}

Key words: biological control, Sclerotinia sclerotiorum (Lib.), endophytic strain, Symphytum officinale L.

\section{INTRODUCTION}

Beans crops of Phaseolus vulgaris L. (21) are highly susceptible to white mildew, a disease caused by the soilinhabiting fungus, Sclerotinia sclerotiorum (Lib.) $(16,22)$. This disease manifests itself in the stem, leaves and beans, arising first in parts closer to the ground. Symptoms are characterized by cottony white mycelia that form compact masses, which usually produce resistant structures called sclerotia with high genetic diversity (11). Depending on the location and extension of the necrosis, the plant may exhibit a yellowish-brown discoloration and die (9). Seeds under attack lose their brightness and become cloudy, leading to weight reduction and causing economic and commercial harm to producers (13).

Generally, white mildew prevention is achieved with the use of specific fungicides. Problems associated with fungicide spraying of crops include failure to achieve pathogen control due to the resistance of pathogen populations, environmental contamination, harm to human health and high economic costs (12).

In this context, biological control appears to be a rational alternative for agriculture and a number of pathosystems are

*Corresponding Author. Mailing address: Department of Structural and Molecular Biology and Genetics, Ponta Grossa State University (UEPG), Uvaranas Campus, Ponta Grossa, PR, Brasil. Tel.: +55 423220 3737. E-mail: mpileggi@onda.com.br 
currently commercially available (15). The use of living organisms that can attack other organisms that cause economic damage to crops is defined as Biological Control (14). This is a strategy used in agroecological systems as well as conventional agriculture based on Integrated Plague Handling (IPH). IPH can result in greater economic viability when compared to the high costs of the exclusive use of the chemical control of plant diseases (1).

Biological Control Agents (BCA) are a valid alternative for use in the control of pests in crops (20). The biological control, or biocontrol, of phytopathogens and diseases is generally achieved by using specific microbial agents or introducing selected microorganisms into the system. In these cases, the isolation of an efficient biocontrol agent must be developed (12). For such, endophytes are currently employed. Endophytic strains live inside plants without causing any apparent damage to their hosts (3). Among endophytic microorganisms, certain fungi and bacteria have proven efficient against phytopathogens, suggesting antimicrobial production (19). Endophytic fungi are isolated from plants and are submitted to tests for antimicrobial activity in order to investigate their potential for agricultural application (7). Studies have indicated that endophytes have potential for biological control due to their antagonistic effect against the fungus S. sclerotiorum (26).

The herbaceous plant Symphytum officinale L. (25), popularly known as comfrey (Boraginaceae), is frequently used for its therapeutic properties. Extracts from comfrey leaves inhibit the germination of fungal pathogens and activate natural plant defense mechanisms (24). These medicinal plants and their potential endophytic interactions are being investigated and have shown promising results concerning the use of endophytes as biocontrol agents against pests and diseases (17).

In virtue of the importance of bean crops, the biocontrol of the phytopathogen S. sclerotiorum using endophytic strains is an excellent economic possibility, as it causes less damage to the environment. The objective of the present study was to select endophytic fungi isolated from comfrey leaves with in vitro antagonistic potential against the phytopathogen $S$. sclerotiorum.

\section{MATERIALS AND METHODS}

\section{Isolation of Endophytes}

Endophytic fungal strains were isolated from comfrey leaves based on the methodology described in Penna (23) with some modifications. For surface sterilization, healthy leaves were washed carefully in running water and petioles were covered with melted paraffin. The material was submerged in $3 \%$ sodium hypochlorite $(\mathrm{NaOCl})$ for $1 \mathrm{~min}, 70 \%$ ethanol for $1 \mathrm{~min}$ and distilled water for $3 \mathrm{~min}$. The leaves were cut into $8 \mathrm{~mm}^{2}$ fragments, which were transferred to Petri dishes containing potato dextrose agar (PDA). As a negative control, $100 \mu \mathrm{L}$ of the distilled water used in the leaf surface sterilization was spread on PDA dishes and incubated at 18 and $28^{\circ} \mathrm{C}$. Fungi were grown in Sabouraud Agar, immersed in plastic tubes with sterilized water and stored at $4^{\circ} \mathrm{C}(6)$.

\section{Biological Assays}

Twelve endophytic fungal strains were used in the present study to evaluate antagonism against an isolate of the phytopathogen $S$. sclerotiorum, using the challenge method.

\section{Assembly of the Challenge Method}

Both the endophyte and the phytopathogen were inoculated on a Petri dish containing Sabouraud agar, each $1 \mathrm{~cm}$ from the edge of the plate. As control tests, fungal strains were inoculated separately on a dish (1 $\mathrm{cm}$ from the edge) and maintained at $28^{\circ} \mathrm{C}$ for 8 days, which was period of time that the mycelia reached maximal growth in the presence of the antagonistic strains and no more growth was observed. Initial tests were developed in triplicate to evaluate the antibiosis of endophytes against $S$. sclerotiorum. Positive results for antagonism were then repeated, with ten repetitions. At the same time, controls for the endophytic and phytopathogen strains (one strain per plate) were incubated at $28^{\circ} \mathrm{C}$ for 15 days, which was the time sufficient for reaching the opposite border under the same conditions as the challenge tests. Evaluation of mycelia growth for each strain in the control and challenge was performed by measuring colony diameters in $\mathrm{mm}$ /day and the data was displayed in graphs, expressed in $\mathrm{mm} / \mathrm{time}$.

\section{T-Test for Comparison of Mycelial Growth}

The t-test was used for the comparison of mean values of mycelia growth for both endophytic and phytopathogenic strains after 8 days both for the control and challenge experiments. The SAS program was used for these analyses (18).

\section{Morphological Identification of Endophytic Strains}

PDA microculture slides were used to identify endophytic fungi, which were covered with glass slip covers and incubated at $28^{\circ} \mathrm{C}$. After 7 and 14 days, slides containing the mycelia of the endophytic fungi were stained with Lactophenol Cotton Blue (LPCB) and observed under an optical microscope (400X). Spore morphology and vegetal structures were compared with a standardized key for fungus identification (10).

\section{Spore Dilution}

In the challenge method, the dishes were incubated at $28^{\circ} \mathrm{C}$ to promote the growth of the strains. Both challenge and control growth of endophytes and phytopathogens (one strain per plate) were tested under the same conditions. One- $\mathrm{cm}^{2}$ plugs of Sabouraud agar containing control and challenge fungal strains were collected with the aid of a sterilized clamp and scalpel. Each plug was placed in a tube containing $1 \mathrm{~mL}$ of $0.9 \% \mathrm{NaCl}$ solution 
and $0.2 \%$ tween. $10^{-1}$ dilution was obtained and $10 \mu \mathrm{L}$ of the spore solution was placed in a Neubauer chamber and visualized under an optical microscope (400X), followed by spore counts.

\section{T-Test for Comparison of Spore Production}

The t-test was used for the comparison of mean values of spore counts produced by endophytic and phytopathogenic strains during the 8-day period in both control and challenge experiments. The t-test was analyzed with the aid of the SAS program(18).

\section{Microorganism Preservation}

Strains that could potentially produce antimicrobial substances against phytopathogenic strains were stored in filter paper straps at $-20^{\circ} \mathrm{C}$ and in Sabouraud agar plugs containing mycelia, immersed in sterilized water and stored at $4^{\circ} \mathrm{C}(6)$.

\section{RESULTS AND DISCUSSION}

Among twelve endophytic strains tested in the challenge methodology, four (Trichophyton sp., Chrysosporium sp., Candida pseudotropicalis and Candida tropicalis) exhibited the best antagonistic activity against the phytopathogen $S$. sclerotiorum. This was the first report of these three genera isolated as endophytes from Symphytum officinale L. (comfrey).

The growth of phytopathogenic and endophytic strains in the challenge experiments reached maximal rate eight days after inoculation. The marks correspond to halo formation between the two strains under challenge, as shown in Fig. 1. Inhibition halos were considered indicators of antibiosis caused by antagonistic substances possibly produced in the culture media.

In vitro antagonism obtained from the challenge technique between endophytes and S. sclerotiorum was also determined in Pileggi et al. (17), suggesting a strong potential for the use of endophytic microorganisms in biological control programs, particularly those producing antagonistic substances. Bell et al. (4) and Durman et al. (8) also observed halos between an endophytic Trichoderma and different pathogenic strains. In the present study, in vitro methods revealed the antagonistic potential of the endophytes against a pathogenic strain. However, in vitro antagonistic activity does not correspond to in vivo disease reduction in all cases, as observed by Bettiol (5) and Andrews (2).

Separate growth of the isolated endophytic fungi and $S$. sclerotiorum (experimental controls) over a 15-day period provided the standardized $100 \%$, as shown in Fig. 2. This figure reveals that, when challenged, both strains stopped growing in just 8 days.

The isolates with the greatest antagonistic effect against $S$. sclerotiorum (probably due to antibiosis) were $C$. pseudotropicalis (50.0\% inhibition), Chrysosporium sp. (48.9\% inhibition), C. tropicalis (47.8\% inhibition) and Trichophyton sp.

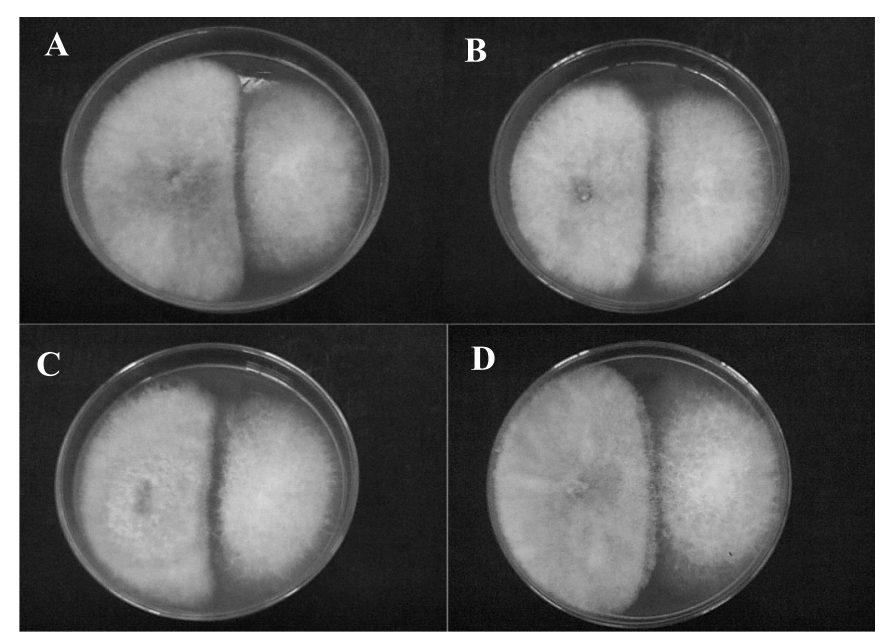

Figure 1. Challenge experimental design between endophytic strains and the phytopathogen S. sclerotiorum. The endophytic strains C. pseudotropicalis (A), Trichophyton sp. (B), C. tropicalis (C) and Chrysosporium sp. (D) are positioned on the left and S. sclerotiorum is positioned on the right.

(46.7\% inhibition) (Fig. 3). The antagonistic effect was revealed by a considerable reduction in the growth rate of $S$. sclerotiorum in the presence of the endophytes when compared to the growth rate in the control experiment. Growth reduction of S. sclerotiorum was also demonstrated by Ethur (9) using the in vitro challenge method with Trichoderma strains isolated as biocontrol agents, in which growth inhibition ranged from $86 \%$ to $94 \%$. In the present study, we observed a reduction in the growth rate of $S$. sclerotiorum ranging from $46.7 \%$ to $50.0 \%$. The data reveal that growth rate of the pathogenic strain in the challenge tests was highly reduced in relation to the control results.

Table 1, which summarizes Fig. 2, shows the growth of $S$. sclerotiorum over the 8-day period challenged against the following endophytic strains: C. pseudotropicalis, C. tropicalis, Chrysosporium sp. and Trichophyton sp., revealing a statistically significant reduction when compared with the growth rate for the same time interval in the control tests. The significant reduction in the $S$. sclerotiorum growth rate in the challenge in comparison to the control indicates possible antimicrobial activity by the endophytic fungi strains against the phytopathogen (Table 1).

Fungal sporulation was studied with the aim of evaluating whether this event was affected by chemical stress among the strains in the challenge tests. Spore counts were performed in a Neubauer chamber at a $10^{-1}$ dilution factor. There was no statistically significant difference in mean spore count values of endophytic and pathogenic strains between the control and challenge (Table 2). Nonetheless, Table 2 shows that, in absolute numbers, spore count values were always greater in the 

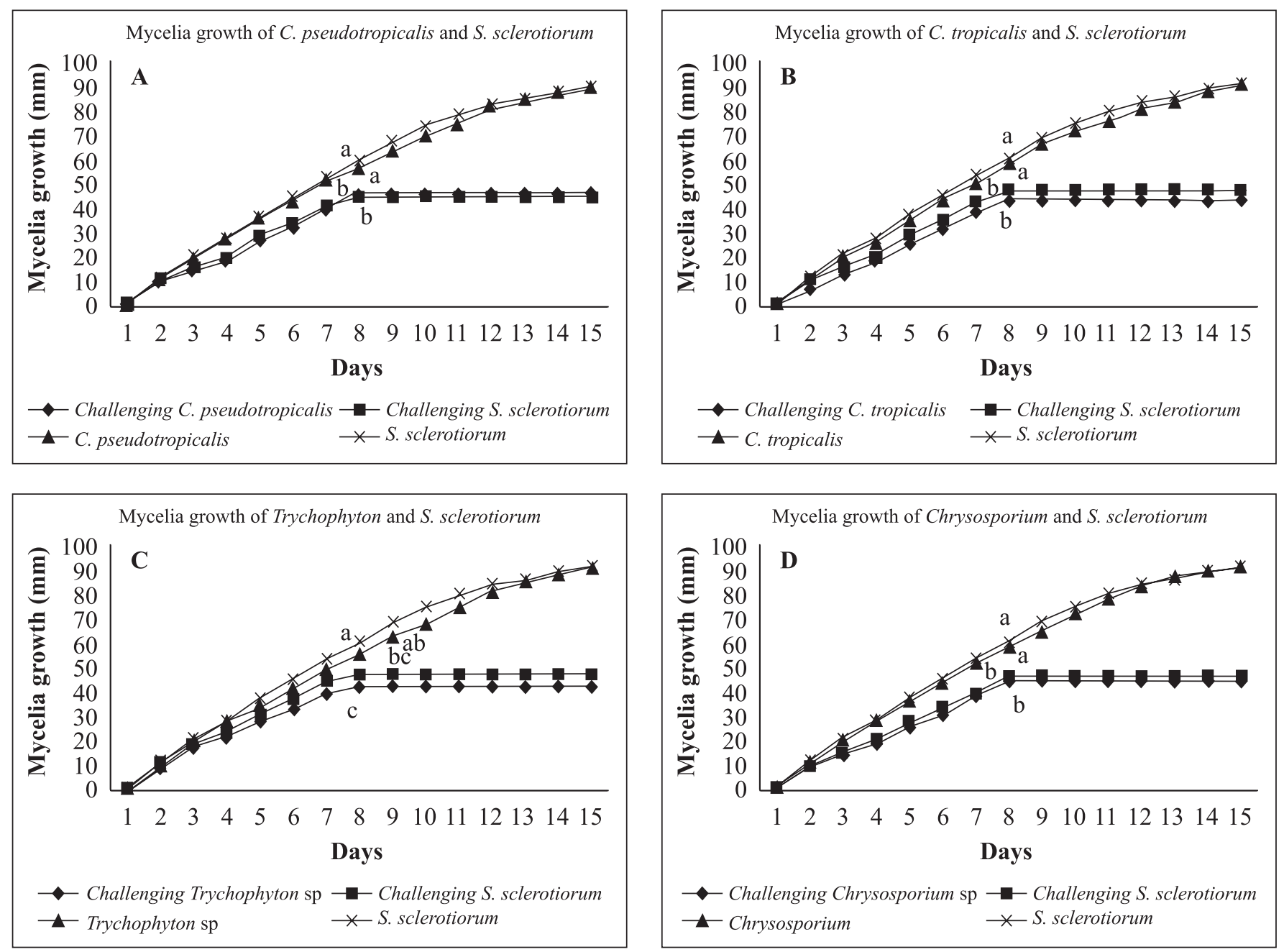

Figure 2. Growth representation of C. pseudotropicalis/S. sclerotiorum strains (A); C. tropicalis/S. sclerotiorum (B); Trichophyton sp./S. sclerotiorum (C); and Chrysosporium sp./S. sclerotiorum (D) in mm/day for during a 15-day control experiment (one strain per Petri dish) and 8-day challenge tests (endophytic/pathogenic strains inoculated in the same Petri dish). Mean values followed by the same letter do not differ statistically, according to t-test at a 5\% level of significance.

challenge than control tests. As sporulation occurs, it is possible that these differences will become significant later on.

The results of the present study suggest the need for further experiments on the antagonistic activity of the endophytic strains against $S$. sclerotiorum using in vivo assays with plants under controlled greenhouse conditions. After these evaluations, the endophytes tested in the present study could be considered for use in S. sclerotiorum biological control programs. Four endophytes were selected for their antagonistic activity against $S$. sclerotiorum. The inhibition halos in the challenge experiments were considered indicative of antibiosis. Pathogen growth reduction of up to $50 \%$ in the antagonistic tests indicates the metabolic activity of endophytic strains in the presence of S. sclerotiorum. No significant difference was found in spore production by the phytopathogen between the control and challenge tests. The in vitro quantitative and qualitative information obtained in the present study indicates that the use of bioactive products from endophytic strains or biological control of $S$. sclerotiorum needs to be studied in greater detail.

\section{ACKNOWLEDGEMENTS}

The authors would like to thank Fabiana Diuk for the isolation of endophytic fungal strains from comfrey $(S$. officinale). 
Table 1. Mycelia growth of S. sclerotiorum in control and challenge tests during an 8-day period against the endophytic fungal strains $C$. pseudotropicalis; Trichophyton sp.; $C$. tropicalis and Chrysosporium sp. The table also shows the mycelia growth of the endophytes C. pseudotropicalis; Trichophyton sp.; C. tropicalis and Chrysosporium sp. in the control and challenge tests during the 8-day period against $S$. sclerotiorum.

\begin{tabular}{|c|c|}
\hline Treatment & $\begin{array}{l}\text { rage diameter } \\
\text { m) on } 8^{\text {th }} \text { day }\end{array}$ \\
\hline 1. Control S. sclerotiorum & $60 \mathrm{a}$ \\
\hline 2. Control C. tropicalis & $58 \mathrm{a}$ \\
\hline 3. Control C. pseudotropicalis & $57 \mathrm{a}$ \\
\hline 4. Control Chrysosporium sp. & $57 \mathrm{a}$ \\
\hline 5. Control Trichophyton sp. & $55 \mathrm{ab}$ \\
\hline 6. S. sclerotiorum with Trichophyton sp. & $48 \mathrm{bc}$ \\
\hline 7. S. sclerotiorum with C. tropicalis & $47 \mathrm{c}$ \\
\hline 8. S. sclerotiorum with Chrysosporium sp. & $46 \mathrm{c}$ \\
\hline 9. C. pseudotropicalis with S. Sclerotiorum & $46 \mathrm{c}$ \\
\hline 10. S. sclerotiorum with C. pseudotropicalis & $45 \mathrm{c}$ \\
\hline 11. Chrysosporium sp. with S. sclerotiorum & $44 \mathrm{c}$ \\
\hline 12. C. tropicalis with S. sclerotiorum & $43 \mathrm{c}$ \\
\hline 13. Trichophyton sp. with $S$. sclerotiorum & $42 \mathrm{c}$ \\
\hline
\end{tabular}

Mean values followed by the same letter do not differ statistically, according to t-test at a $5 \%$ level of significance.

Table 2. Spore counts of endophytic and pathogenic fungal strains in control and challenge tests at a $10^{-1}$ dilution factor over an 8-day period.

\begin{tabular}{lc}
\hline \multicolumn{1}{c}{ Strains } & $\begin{array}{c}10^{-1} \text { Dilution } \\
\text { Factor }\end{array}$ \\
\hline Control S. sclerotiorum & $\mathbf{3 2 . 1 0}^{-1} \mathrm{a}$ \\
S. sclerotiorum with C. pseudotropicalis & $\mathbf{4 0 . 1 0}^{-1} \mathrm{a}$ \\
S. sclerotiorum with Trichophyton sp. & $\mathbf{3 4 . 1 0}^{-1} \mathrm{a}$ \\
S. sclerotiorum with C. tropicalis & $\mathbf{3 7 . 1 0}^{-1} \mathrm{a}$ \\
S. sclerotiorum with Chrysosporium sp. & $\mathbf{3 9 . 1 0}^{-1} \mathrm{a}$ \\
Control C. pseudotropicalis & $\mathbf{2 9 . 1 0}^{-1} \mathrm{a}$ \\
C. pseudotropicalis with S.clerotiorum & $\mathbf{3 4 . 1 0}^{-1} \mathrm{a}$ \\
Control Trichophyton sp. & $\mathbf{3 1 . 1 0}^{-1} \mathrm{a}$ \\
Trichophyton sp. with S. clerotiorum & $\mathbf{3 7 . 1 0}^{-1} \mathrm{a}$ \\
Control C. tropicalis & $\mathbf{3 5 . 1 0}^{-1} \mathrm{a}$ \\
C. tropicalis with S. sclerotiorum & $\mathbf{4 2 . 1 0}^{-1} \mathrm{a}$ \\
Control Chrysosporium sp. & $\mathbf{3 3 . 1 0}^{-1} \mathrm{a}$ \\
Chrysosporium sp. with S. sclerotiorum & $\mathbf{4 1 . 1 0}^{-1} \mathrm{a}$ \\
\hline
\end{tabular}

Mean values followed by the same letter do not differ statistically, according to t-test at a $5 \%$ level of significance.

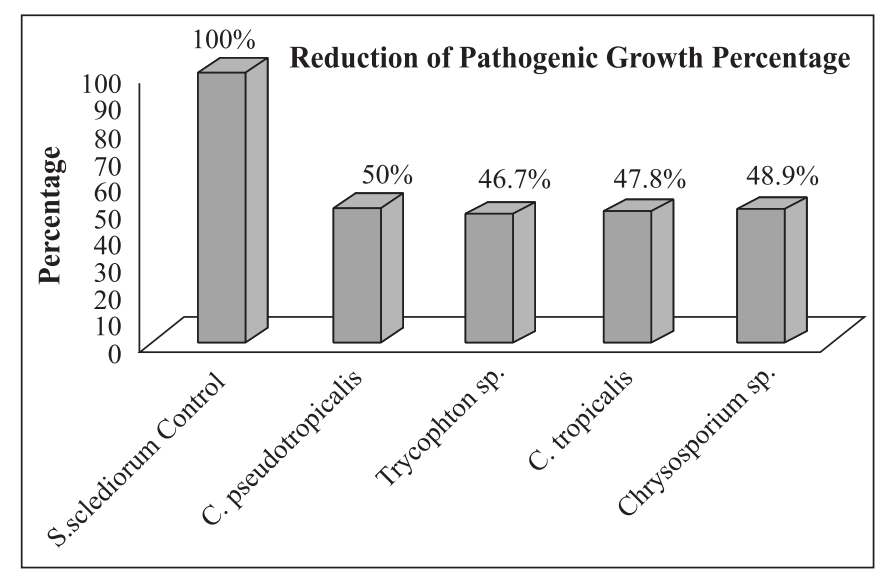

Figure 3. Inhibition percentage of the pathogen S. sclerotiorum in the presence of endophytic strains in challenge tests ranging from $46.7 \%$ to $50.0 \%$. The growth rate of $S$. sclerotiorum in the control was standardized as $100 \%$.

\section{RESUMO}

\section{Seleção de fungos endofíticos de confrei (Symphytum officinale $\mathrm{L}$.), buscando controle biológico in vitro do fitopatógeno Sclerotinia sclerotiorum (Lib.)}

O controle biológico consiste no uso de organismos que atacam outros que causam danos a culturas de plantas. Esta é uma estratégia muito utilizada no Controle Integrado de Pragas (CIP). O mofo branco, causado por Sclerotinia sclerotiorum (Lib.), causa danos em culturas de feijão. Este fungo é encontrado no solo e seus sintomas são caracterizados por lesões úmidas cobertas por micélios algodonosos, crescidos a partir do solo e/ ou da planta hospedeira. Há relatos de pesquisas buscando agentes potenciais de controle biológico isolados de plantas para controlar fungos fitopatogênicos. Entre estes agentes encontram-se os microrganismos endofíticos, habitantes de espaços intercelulares de tecidos vegetais, muitas vezes responsáveis pela produção de substâncias antimicrobianas. Este trabalho teve por objetivo selecionar linhagens endofíticas isoladas de folhas de confrei (Symphytum officinale L.), com potencial de antagonismo in vitro contra a linhagem fitopatogênica $S$. sclerotiorum. Doze linhagens de fungos endofiticos foram utilizadas na técnica de desafio em placa contra um isolado patogênico de $S$. sclerotiorum. Com o auxílio desta técnica, quatro linhagens com melhor atividade antagonística contra S. sclerotiorum foram selecionadas. Zonas de inibição no crescimento da linhagem patogênica foram consideradas como indicativo de antibiose. Foram efetuadas análises da porcentagem de elongação micelial com e sem antagonismo, mostrando resultados de $46,7 \%$ a $50,0 \%$ de redução no 
crescimento micelial do fitopatógeno. Estas análises consistiram de avaliações das medidas do crescimento em $\mathrm{mm} / \mathrm{dia}$ das linhagens endofíticas/patogênica em testes de antagonismo.

Palavras-chave: controle biológico, Sclerotinia sclerotiorum (Lib.), linhagens endofíticas, Symphytum officinale L.

\section{REFERENCES}

1. Altieri, M. (2001). Agroecologia: a Dinâmica Produtiva da Agricultura Sustentável. Editora da UFRGS, Porto Alegre.

2. Andrews, J.H. (1992a). Biological Control in the Phyllosphere. Аnnu. Rev. Phytopathol. 30, 603-635.

3. Azevedo, J.L. (1999). Botânica uma Ciência Básica ou Aplicada? Ver. Bras. Bot. 22(2), 225-229.

4. Bell, D.K.; Wells, H.D.; Markham, C.R. (1982). In vitro Antagonism of Trichoderma Species Against Six Fungal Plant Pathogens. Phytopathology. 72 (4), 379-382.

5. Bettiol, W. (1991). Seleção de Microrganismos Antagônicos a Fitopatógenos. In: Bettiol, W. org. Controle Biológico de Doenças de Plantas. EMBRAPA-CNPDA. Jaguariúna, p. 223-236.

6. Castellani, A. (1939). Viability of some pathogenic fungi in distilled water. J. Trop. Med. Hyg. 42, 225-226.

7. Corrado, M.; Rodrigues, K.F. (2004). Antimicrobial Evaluation of Fungal Extracts Produced by Endophytic Strains of Phomopsis $s p$. J. Basic Microbiol. 44(2), 157-160.

8. Durman, S.; Menendez, A.; Godeas, A. (1999). Evaluación de Trichoderma spp. como antagonista de Rhizoctonia solani in vitro y como biocontrolador del camping-off de plantas de tomate en invernadero. Rev. Argent. Microbiol. 31, 13-18.

9. Ethur, Z.L.; Cembranel, Z.C.; Silva, F.C.A. (2001). Seleção de Trichoderma spp. Visando ao Controle de Sclerotinia sclerotiorum, in vitro. Ciência Rural. 31(5), 885-887.

10. Larone, H.D. (1993). Medically Important Fungi: A Guide to Identification. Ed. American Society for Microbiology, Washinngton, D.C.

11. Meinhardt, W.L.; Wulff, A.N.; Bellato, M.C.; Tsai, M.S. (2002). Telomere and Microsatellite Primers Reveal Diversity Among Sclerotinia sclerotiorum Isolates From Brazil. Fitopatol. Bras. 27, 211-215.

12. Melo, S.I.; Azevedo, L.J. (1998). Controle Biológico. Embrapa, Jaguariúna, SP.
13. Michereff, J.S. (2005). Doenças Causam Sérios Prejuízos na Safra de Feijão em Pernambuco. Summa Phytopathol. 31(2), 173-180.

14. Monarco, C.; Sisterna, M.; Perelló, A.; Bello, D.G. (2004). Preliminary Studies on Biological Control of the Blackpoint Complex of Wheat in Argentina. World J. Microbiol. Biotechnol. 20(3), 285-290.

15. Moura, B.A.; Romeiro, S.R. (1999). In Vitro Evaluation of Actinomycetes as Antagonists to Ralstonia solanacearum. Ciência e Agrotec. 23(2), 281-288.

16. Oliveira, F.H.S. (2005). Manejo do Mofo Branco. Revista DBO Agrotecnologia Ano 2 - $\mathrm{n}^{\circ} 4$ Maio/Junho.

17. Pileggi, M.; Raiman, P.M; Micheli, A; Beatriz, S.; Bobalto,V. (2002). Antimicrobial Action and Endophytic interaction in Symphytum officinale L.; Publicatio UEPG. 8(1), 47-55.

18. SAS Institute Inc. (1993). SAS System, 18v. Cary, NC.

19. Souza, L.Q.A.; Souza, L.D.A.; Astolfi Filho, S.; Belém Pinheiro, L.M.; Sarquis, M.I.M.; Pereira, O.J. (2004). Atividade Antimicrobiana de Fungus Endofíticos Isolados de Plantas Tóxicas da Amazônia: Palicourea longiflora (aubl.) rich e Strychnos cogens Bentham. Acta Amazônica. 34(2), 185-195.

20. Vrije, T.; Antoine, N.; Buitelaar, M.R.; Bruckner, S.; Dissevelt, M.; Durand, A.; Gerlagh, M.; Jones, E.E.; Lüth, P.; Oostra, J.; Ravensberg, W.J.; Renaud, R.; Rinzema, A.; Weber, F.J.; Whipps, J.M. (2001). The Fungal Biocontrol Agent Coniothyrium minitans: Production by Solid-state Fermentation, Application and Marketing. Appl. Microbiol. Biotechnol. 56(1-2), 58-68.

21. Harris, J.A.; Sinnott, E.W. (1921). The Vascular Anatomy of Normal and Variant Seedlings of Phaseolus vulgaris. Proc. Natl. Acad. Sci. U.S.A. 7(1), 35-41

22. Calonge, F.D. (1970). Notes on the ultrastructure of the microconidium and stroma in Sclerotinia sclerotiorum. Arch Mikrobiol. 71(2), 191-195.

23. Penna, E.B. da S. (2000). Microrganismos endofíticos em erva-mate (Ilex paraguariensis, ST. HIL.) e variabilidade genética em Phyllosticta sp. por RAPD. Curitiba. 123 f. Dissertação (Mestrado em Genética) - Universidade Federal do Paraná.

24. Karavaev, V.A.; Solntsev, M.K.; Iurina, T.P.; Iurina, E.V.; Poliakova, I.B.; Kuznetsov, A.M. (2001). Antifungal activity of aqueous extracts from the leaf of cowparsnip and comfrey. Izv. Akad. Nauk. Ser. Biol. (4), 435-441.

25. Klein, F. (1952). Antiphlogistic application with Symphytum officinale. Hippokrates. 23(19), 550-552.

26. Sessitsch, A.; Reiter, B.; Berg, G. (2004). Endophytic bacterial communities of field-grown potato plants and their plant-growthpromoting and antagonistic abilities. Can. J. Microbiol. 50(4), 239249 . 